\title{
International Conference on the Conservation of the Lesser Spotted Eagle, Košická Belá, Slovakia, 2014
}

\author{
Medzinárodná konferencia o ochrane orla krikl’avého, Košická Belá, Slovensko, 2014
}

\author{
Zuzana GUZIOVÁ \& Miroslav DRAVECKÝ
}

\begin{abstract}
The International Conference on the Conservation of the Lesser Spotted Eagle (Aquila pomarina) was held on September 25-27, 2014 in Lesanka Gesthouse at Košická Belá, Slovakia. It was organised by Raptor Protection of Slovakia (RPS) in cooperation with Východoslovenská energetika Holding a.s. The conference dealt with (i) delivering further inputs for updating the European Action Plan for the species, (ii) sharing information on biology and ecology of the species, and (iii) exchange of experience with best practice and innovative species conservation measures. A total of 59 participants from 14 countries attended the conference. The agenda included 17 presentations and 7 posters. Some of the contributions are published in Slovak Raptor Journal volume 9 (2015) as full papers, and a further 23 contributions are published as abstracts. The conference also included two field trips during which participants had the opportunity to observe the installation of console barriers on poles of $22 \mathrm{kV}$ power lines, and typical habitats of the lesser spotted eagle. The conference was organized within the framework of the project LIFE09NAT/SK/000396 Conservation of Aquila pomarina in Slovakia, implemented by Raptor Protection of Slovakia, Východoslovenská energetika Holding a.s., Stredoslovenská energetika, a.s. and Stredoslovenská energetika-Distribúcia, a.s. The project was cofinanced by EU-LIFE and the Ministry for Environment of the Slovak Republic.
\end{abstract}

Abstrakt: Medzinárodná konferencia o ochrane orla krikl’avého (Aquila pomarina) sa konala 25. - 27. septembra 2014 v Penzióne Lesanka v Košickej Belej na Slovensku. Zorganizovala ju Ochrana dravcov na Slovensku (RPS) v spolupráci s Východoslovenskou energetikou Holding a.s. Konferencia bola zameraná na prípravu podkladov pre aktualizáciu európskeho akčného plánu pre orla krikl’avého, zdiel’anie informácií o biológii a ekológia druhu a na výmenu skúseností s osvedčenými alebo inovatívnymi opatreniami pre zachovanie orla krikl’avého. Konferencie sa zúčastnilo celkom 59 účastníkov zo 14 krajín. Na konferencii odznelo 17 príspevkov a bolo prezentovaných 7 posterov. Niektoré z týchto príspevkov sú publikované $\mathrm{v}$ časopise Slovak Raptor Journal 9 (2015), d’alších 23 príspevkov sú publikované formou konferenčných abstraktov. Program konferencie zahŕňal aj 2 exkurzie, počas ktorých mali účastníci možnost' vidiet' ukážku inštalácie konzolových chráničiek na stĺpoch 22 $\mathrm{kV}$ elektrického vedenia a typické biotopy orla krikl'avého. Konferencia bola organizovaná v rámci projektu LIFE09NAT/SK/000396 Ochrana orla krikl'avého na Slovensku, ktorý realizovala Ochrana dravcov na Slovensku, Východoslovenská energetika Holding a.s., Stredoslovenská energetika, a.s. a Stredoslovenská energetika-Distribúcia, a.s. Projekt bol spolufinancovaný Európskou úniou prostredníctvom finančného nástroja LIFE a Ministerstvom životného prostredia Slovenskej republiky.

Key words: lesser spotted eagle conference, presentations, posters, Aquila pomarina, LIFE

Zuzana Guziová, Miroslav Dravecký, Raptor Protection of Slovakia, Kuklovská 5, 84104 Bratislava, Slovakia. E-mail: guziova@dravce.sk, dravecky@dravce.sk.

Acknowledgements: The conference was held with financial support from Východoslovenská energetika Holding a.s., and was co-financed through the European Union's LIFE Programme and the Ministry for Environment of the Slovak Republic. The organizers would like to thank everyone who contributed to the preparation and holding of the conference, and to all of the participants for their valuable data and experience.

The lesser spotted eagle is a migratory species. It breeds in Central and Eastern Europe and further south-east in Turkey, and it winters in Africa (BirdLife International 2015). In Europe, it has suffered a major decline in many countries, especially at the western and southern borders of its range. In 1997, an Action Plan for the
Lesser Spotted Eagle was adopted in order to set up an international framework for action for various entities concerned with conservation of the lesser spotted eagle. This Action Plan included outcomes from the second meeting of the International Lesser and Greater Spotted Eagle Working Group in Kemeri (Latvia), hosted by the 


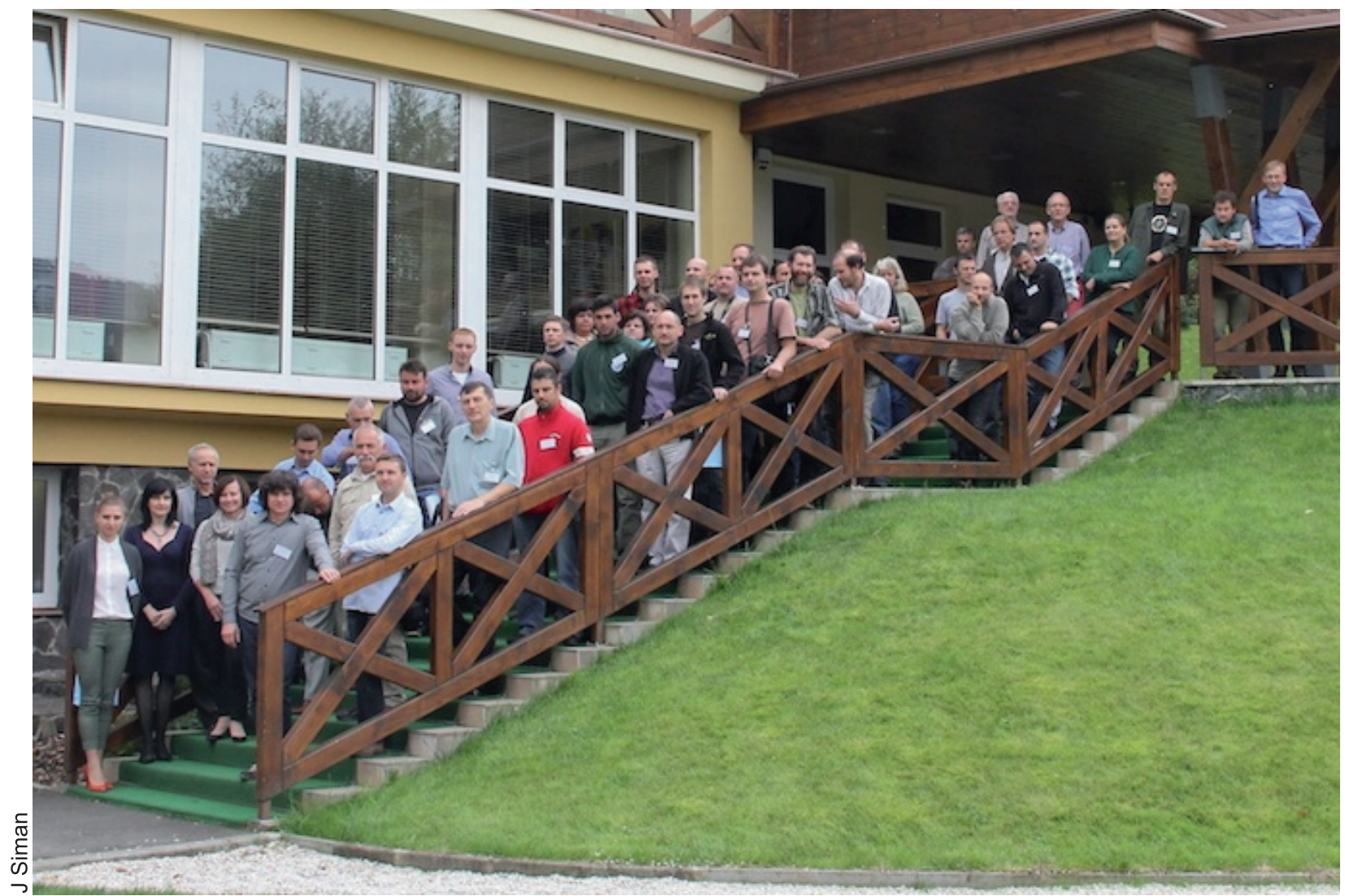

Fig. 1. Participants of the International Conference on the Conservation of the Lesser Spotted Eagle at Košická Belá, Slovakia, 2014.

Obr. 1. Účastníci Medzinárodnej konferencie o ochrane orla kriklavého v Košickej Belej, Slovensko, 2014.

Latvian Ornithological Society and organised by BirdLife International and the World Working Group on Birds of Prey (Meyburg et al. 2001). The Action Plan has not been updated since then. However, efforts recently started to update this important document and create a modern conservation action framework for the species that receives priority attention in the European Union.

The LIFE Project 08/NAT/RO/000501 "Conservation of Aquila pomarina in Romania" enabled the Environmental Protection Agency in Sibiu, in cooperation with its project partners Milvus Group and the Romanian Ornithological Society, to organise the International Conference for Updating the European Action Plan for the Lesser Spotted Eagle. The meeting was held from October 31 to November 2, 2013 in Bâlea Cascadă, Făgăraș Mountains, Romania. The initiative was received with wide enthusiasm as shown by the participation from many EU member states, as well as countries outside the EU: altogether 50 ornithologists from 15 countries attended the meeting (http://tinyurl.com/ pfb5la7). Threats posed to the lesser spotted eagle and limiting factors influencing the population were discussed by present experts along with actions to address them, both representing a valuable input for the new Action Plan.

As a follow-up to the conference in Romania, the International Conference on the Conservation of the Lesser Spotted Eagle (Aquila pomarina) was held on September 25-27, 2014 in Lesanka Gesthouse at Košická Belá, Slovakia. It was organised by Raptor Protection of Slovakia (RPS) in cooperation with Východoslovenská energetika Holding a.s. The conference was organized within the framework of the project LIFE09NAT/SK/000396 Conservation of Aquila pomarina in Slovakia (LIFE project), implemented by Raptor Protection of Slovakia, Východoslovenská energetika Holding a.s., Stredoslovenská energetika, a.s. and 
Tab. 1. List of conference presentations and posters on Aquila pomarina biology, population status and trends presented at the International Conference on the Conservation of the Lesser Spotted Eagle at Košická Belá, Slovakia, 2014.

Tab. 1. Prehl'ad konferenčných príspevkov a posterov o biológii, stave a trende populácie Aquila pomarina prezentovaných na Medzinárodnej konferencii o ochrane orla kriklavého v Košickej Belej, Slovensko, 2014.

Presentation title Slovak Raptor Journal 9/2015

Conservation of the lesser spotted eagle in Slovakia

Guziová Z: Conservation of the lesser spotted eagle in Slovakia supported by the Project LIFE09NAT/SK/000396

Dravecký M: Distribution, abundance and trend of the lesser spotted eagle population in Slovakia

Maderič B: Conservation management of the lesser spotted eagle population in Slovakia

$\mathrm{Ab}$

$\mathrm{Fp}$

$\mathrm{Ab}$

Status and trend of the lesser spotted eagle

Maniakowski M: Protection of the LSE in selected Natura 2000 sites in Poland

Stoychev S: Conservation of the lesser spotted eagle in Bulgaria in the frame of the project Preserve Key Forest

Habitats of the lesser spotted eagle (Aquila pomarina) in Bulgaria

Pakul P: Population status and trends of lesser spotted eagle in Belarus

\section{Management, research and monitoring of the lesser spotted eagle}

Meyburg B-U: Lesser spotted eagle (Aquila pomarina) nestling management in Brandenburg (Germany) 2004-2014

Treynis R: Enhancement of lesser spotted eagle nest site protection: does erection of artificial nest is a suitable measure? Meyburg B-U: Some highlights from 22 years of satellite telemetry with lesser spotted eagles

Peške L': Year round migration and breeding of an adult female LSE from Liptov (Slovakia) as revealed with GPS-GSM tag

Bartoszuk K: Aquila dataloggers

Sellis U: Habitat utilization by the lesser spotted eagle in agricultural landscape as revealed by satellite telemetry:

preliminary results

Meyburg B-U: Lesser spotted eagles (Aquila pomarina) and wind power

Abel U: Changing habitat use of the lesser spotted eagle in Estonia in 1990-2010: Increasing tolerance to human activity

Väli Ü: Effects of agricultural land use patterns on the habitat selection, foraging behaviour and reproductive success

of the lesser spotted eagle in Estonia

Treynis R: Should we consider intraspecific competition when selecting priority sites for lesser spotted eagle conservation?

Meyburg B-U: Mortal danger - do not fly to Istanbul during bird migration!

\section{Posters}

Väli Ü: Breeding phenology of the lesser spotted eagle at the northern range limit: Is the disturbance sufficiently long banned? Väli Ü: Annual adult survival and turnover rates in the Baltic lesser spotted eagle population.

Bergmanis U: Agricultural land change impact assessment on the lesser spotted eagle (Aquila pomarina)

foraging habitats in Latvia.

Domashevskiy S \& Gavryliuk M: Current status of the lesser spotted eagle in Ukraine.

Garbe U: LIFE Schreiadler Projekt im Biosphärenreservat Schorfheide Chorin.

Regional Directorate of State Forests in Bialystok, Poland: Protection of the lesser spotted eagle in selected

NATURA 2000 sites (LIFE08NAT/PL/000510)

Ab - abstract - presentations published as an abstracts in Slovak Raptor Journal 9/2015 in Dravecký \& Guziová (eds) 2015 / Ab abstrakt - prednášky publikované ako abstrakty v Slovak Raptor Journal 9/2015 v článku Dravecký \& Guziová (eds) 2015.

Fp - full paper - presentations published as an full papers in Slovak Raptor Journal 9/2015 / Fp - celý článok - prednášky publikované ako celé články v Slovak Raptor Journal 9/2015

Stredoslovenská energetika-Distribúcia, a.s., EU through LIFE Programme and the Ministry for Environment cofinanced the project.

The conference focused on delivering further inputs for updating the European Action Plan for the species (Recovery Plan for the Lesser Spotted Eagle) and sharing information on biology and ecology of the species and effective species conservation measures. In particular, the following topics were covered by the Conference (i) recent population status and trends, (ii) species endangering factors, and (iii) practical conservation activities and experiences.

Jozef Chavko, Chairman of Raptor Protection of Slovakia opened the conference. An opening address was also given by Marián Mešter from Východoslovenská energetika Holding a.s., in which he presented environmental policy and actions by his company as well as VSE's contribution to the project LIFE09NAT/SK/000396 Conservation of Aquila pomarina in Slovakia. 


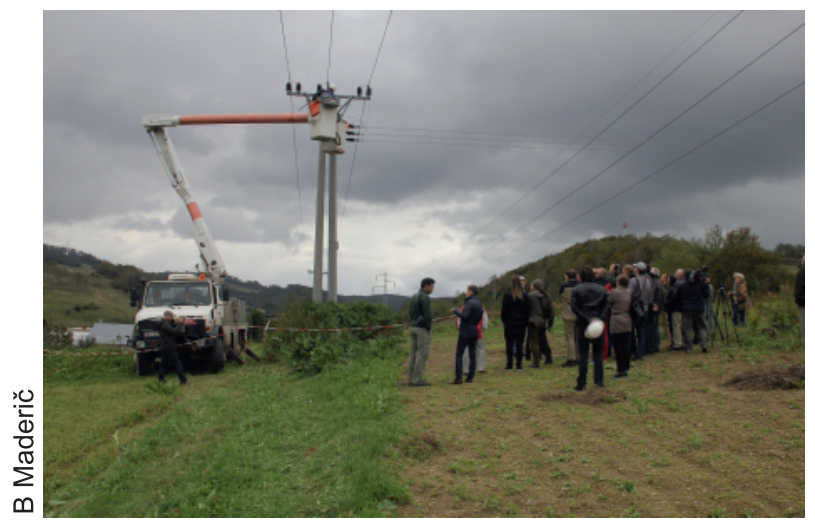

Fig. 2. Participants of the Conference during field presentation of insulation $22 \mathrm{kV}$ power lines consoles under full (not switch off) electricity.

Obr. 2. Účastníci konferencie počas ukážky izolácie konzol 22 kV vedenia pod plným (nevypnutým) elektrickým napätím.

The first section of the conference was dedicated to the conservation of the lesser spotted eagle in Slovakia. In this section, the Slovakian LIFE project was introduced as well as distribution, abundance and trend of the lesser spotted eagle population in Slovakia. This section concluded with a comprehensive description of conservation management of the lesser spotted eagle in Slovakia (Tab. 1).

The second section of the conference focused on the status and trends in the lesser spotted eagle populations in selected EU and non-EU countries. Among others presentations were made of two LIFE projects: one from Poland, LIFE08 NAT/PL/000510 Restoring Populations of Lesser Spotted Eagle at Chosen Areas of Natura 2000 (http://tinyurl.com/qdsdp9c), and the other from Bulgaria, LIFE12 NAT/BG/001218 Preserve Key Forest Habitats of the Lesser Spotted Eagle (Aquila pomarina) in Bulgaria (http://www.eagleforests.org/ en/project-life.html).

Management, research and monitoring of the lesser spotted eagle were the focus of the third conference section. This section also included interesting information resulting from satellite telemetry, including on migration.

The second day of the conference, facilitated by Umberto Gallo-Orsi, was dedicated to working on inputs for the Recovery Plan for the Lesser Spotted Eagle. The participants discussed major factors causing unfavourable status of the lesser spotted eagle and specific conservation measures for the species recovery. All outputs from the debate are included in the document entitled Draft
Recovery Plan for the Lesser Spotted Eagle delivered with the Final Report of the Slovakian LIFE project.

The conference included two field trips during which participants (Fig. 1) had the opportunity to observe the installation of console barriers on poles of 22 $\mathrm{kV}$ power lines (Fig. 2), and typical lesser spotted eagle habitats in Slovenský kras and Volovské vrchy Special Protection Areas.

A total of 59 participants from 14 countries attended the conference (Fig. 1). The agenda included 17 presentations and 7 posters. Some of the contributions are published in Slovak Raptor Journal volume 9 (2015) as full papers, and a further 23 contributions are published as abstracts (Tab. 1).

\section{References}

BirdLife International 2015: Species factsheet: Clanga pomarina. Downloaded from http://www.birdlife.org on April 1, 2015.

Meyburg B-U, Haraszthy L, Strazds M \& Schäffer N 2001: European Union species action plan for lesser spotted eagle (Aquila pomarina). In: Schäffer N \& Gallo-Orsi U (eds), European Union action plans for eight priority bird species: bittern (Botaurus stelaris), ferruginous duck (Aythya nyroca), Steller's eider (Polysticta stelleri), lammergeier (Gypaetus barbatus), greater spotted eagle (Aquila clanga), lesser spotted eagle (Aquila pomarina), Bonelli's eagle (Hieraaetus fasciatus), little bustard (Tetrax tetrax). Office for Official Publications of the European Communities, Luxembourg, 247.

Project LIFE08NAT/RO/000501 Conservation of Aquila pomarina in Romania. Downloaded from http://pomarina.ro/index.php?option=com_con-

tent\&view $=$ article\&id $=207 \% 3$ Aconferin-internaiona 1-in-romania-pentru-actualizarea-planului-europeande-aciune-pentru-acvila-iptoare-mic $\&$ catid $=1 \% 3 \mathrm{Al}$ atest-news\&Itemid $=64 \&$ lang $=\mathrm{EN}$ on April 1, 2015.

Project LIFE08NAT/PL/000510 Restoring populations of lesser spotted eagle at chosen areas of Natura 2000 downloaded from http://ec.europa.eu/environment/life/project/Projects/index.cfm?fuseaction=search.dspPage\&n_proj_id=3547 on April 1, 2015.

Project LIFE12NAT/BG/001218 Preserve key forest habitats of the lesser spotted eagle (Aquila pomarina) in Bulgaria downloaded from http://www.eagleforests.org/en/project-life.html on April 1, 2015. 